\title{
Determinants of Firm Capital Structure: Empirical Evidence From Vietnam
}

\author{
Hieu Thanh Nguyen $^{1} \&$ Anh Huu Nguyen ${ }^{1}$ \\ ${ }^{1}$ School of Accounting and Auditing, National Economics University, Vietnam \\ Correspondence: Hieu Thanh Nguyen, School of Accounting and Auditing, National Economics University, \\ Vietnam.
}

Received: February 26, 2020

Accepted: March 25, 2020

Online Published: June 28, 2020

doi:10.5430/ijfr.v11n4p10

URL: https://doi.org/10.5430/ijfr.v11n4p10

\begin{abstract}
The paper aims to investigate the factors affecting firm capital structure in the context of Vietnam. The research sample includes 290 non-financial listed companies on Vietnamese stock market. This study applied Generalized Method of Moments (GMM) to explain the research results. The paper investigates six factors influencing on firm capital structure including return on assets (ROA), return on equity (ROE), firm size, tangible assets, risks, and growth. The empirical results show that return on assets, tangible assets, risks, and growth have a statistically significant positive effect on the firm capital structure while return on equity has a statistically significant negative effect on the firm capital structure. In addition, when dividing companies into sectors, the study realized that determinants of capital structure in some sectors are consistent with results for entire sample. Finally, firm size has the same impact on capital structure in oil \& gas companies and material companies whereas it is not statistically significant for other companies. These evidences provide a new insight to managers on how to determine the reasonable capital structure.
\end{abstract}

Keywords: capital structure, financial, leverage, sector, Vietnam

\section{Introduction}

In term of practices, capital structure solutions are always a top concern of businesses. In fact, there still exist inadequacies in financial management in corporations especially capital structure management. The existence of an inappropriate capital structure in corporation caused both inefficiencies in performance of the Corporations and put corporation at risk.

In term of theory, study of the capital structure attracting many researchers around the world. Since the study of Modiglani \& Miller (1958), there are many studies on determinants of capital structure, both developed countries and developing countries. In developed countries, notable researches are: Rajan and Zingales (1995) in countries of G7, Burgman (1996) in the United States, Chen (2003) in China, Akhtar \& Oliver (2009) in Japan, Mustilli (2018) in Italy. Also, in developing countries, remarkable researches included: Booth et al. (2001), Trinh \& Phuong (2016) in Vietnam. However, there is no agreement between the studies on the degree of influencing factors on capital structure. Some authors argued that firm size has the positive effect on capital structure (Trinh \& Phuong, 2016; Akgul and Sigali, 2018; Huong, 2018), but some argue that firm size has the negative effect on capital structure (Al-Singlawi and Aladwan, 2016) or has no statistically significant impact on capital structure (Guruswamy and Marew, 2016). Besides, previous researches normally studied determinants on capital structure in whole group of companies (Huang and Song, 2002; Fraser et al., 2006) or a specific type of companies (Sheikh and Wang, 2011 at manufacturing firms; Almanaseer, 2019 at banks). Very few studies have conducted research for various type of companies and then make comparison of the determinants of capital structure among companies. In addition, studies have used data long time ago (i.e. Fauzi et al., 2013 investigates determinants of capital structure of listed firm in New Zealand for the period 2007-2011; Kiraci \& Aydin, 2018 used data from 2004 -2015; Huong, 2018 used data for period from 2008 to 2015). There haven't been studies updated in recent years. Moreover, researches on the factors affecting the capital structure have been carried out mainly in developed countries for decades while very few studies in developing countries and in transitional economies like Vietnam. Therefore, this topic needs to be researched in Vietnam to provide more empirical evidences on factors affecting capital structure to supplement the literature of capital structure. 
This study was conducted in Vietnam with a sample of 290 listed companies and divided into 8 groups of sectors to review the current status of capital structure in Vietnam and explore determinants of capital structure in the whole group and in specific group. Data used for this study in the period from 2010 to 2018 and ROA, ROE, firm size, tangibility, sale growth and volatility of ROA are impact variables. The regression results obtained from GMM regressions are basis for discussions and implications to business managers, investors and bank officers in making decisions.

\section{Theoretical Basis and Literature Review}

\subsection{Theoretical Basis}

Modigliani and Miller theory: According to the theory, the mainly firm value's determinant is firm assets. Firm's assets are financed from loan or owners' contribution. However, the Modigliani and Miller theory indicated that regardless of any type of capital structure, issuing shares or issuing bonds, the firm value is unchanged. The modern capital structure is based on the assumptions made by Modigliani and Miller (1958), whereby, in the absence of taxes, the value of the debt owed enterprise is equal to the value of the non-borrowing firm. Modigliani and Miller theory is the basis for economists to explore and develop studies of capital structure.

Trade - off theory: Trade-off theory was introduced by Kraus and Litzenberger (1973). The firm's capital is determined based on the trade-off between the benefits of the tax shield (due to tax deductible interest) and the cost of financial exhaustion. The more loan a business borrows, the greater the benefit of the tax shield is. However, together with tax incentive, the company also face with the risk of bankruptcy when the debt becomes due, but the company are not affordable to pay. The trade-off theory helps to explain the existence of differences in capital structure of industries. The managers may change the ratio of debt to total assets to adapt with the changes of economic conditions.

Pecking-order theory: This theory points out that there is an order in the use of internal and external financing sources. From the investor's perspective, equity and debt are both risky, however, the level of risk in equity is higher. Thus, shareholders require a higher rate of return. Therefore, according to pecking-order theory, companies will choose company's retained earnings before debt for financing its operation.

Agency theory: The separation between ownership and management has been the material premise for the theories about the relationship between shareholders and company managers. In the second half of the $20^{\text {th }}$ century, many theories about the relationship between shareholders and company managers appeared such as the theory of representation or agency theory (Jensen \& Meckling, 1976; Jensen, 1986). According to this theory, shareholders will have the right to appoint management positions of the company. Those who are elected will be given the authority to make decisions of capital.

\subsection{Literature Review}

Huang and Song (2002) studied the factors affecting the capital structure of more than 1,000 Chinese companies listed on the stock market. Capital structure in this study was measured by the ratio of debt to total assets. Huang and Song (2002) used the OLS method and the Tobit model. The results have shown that the capital structure is positively correlated with firm size, tax shield, the ratio of fixed assets to total assets but negatively correlated with firm's earnings and firm type. This study also showed that ownership structure also affects the capital structure of companies in China.

Chen (2004) also conducted research on the sample of firms in China like Huang and Song (2002) but in this study there are 77 large companies listed in China. The author explored the determinants of capital structure of listed companies. Thus, those variables included profitability, growth, tangibility, cost of financial exhaustion and non-debt tax shields were employed in the study. The ratio of debt to total assets represents for capital structure in this study. The research results showed that the rate of return and firm size have a negative impact on capital structure, while the growth rate and tangibility have the positive effect on capital structure. In addition, research's results showed that Chinese companies prefer to use short-term debt over long-term debt.

Fraser et al. (2006) studied the relationship between state protection and capital structure in developing countries. The data used in this study from firms listed on Malaysian Stock Exchange of the period from 1990 to 1999. The dependent variable is the leverage calculated by the book value of total debt to total assets. Political patronage, firm size, tangible asset, ROA, investment opportunities are independent variables. Using FEM regression and cross-data analysis of 257 Malaysian companies, the authors concluded that: size, profitability and tangibility have positive effect on firm leverage. However, investment opportunities (as measured by the market-to-book asset ratio) have no 
impact on firm leverage. ROA has negative effect on leverage and political patronage is positively and statistically significant factor of firm leverage.

Akhtar and Oliver (2009) examined determinants of capital structure among Japanese multinational and domestic corporations. Leverage in this study was measured by the ratio of long-term debts to total assets and market value of equity. The research sample included 360 companies in 10 years from 1993 to 2003. Profitability, size, firm age, assets mortgaged, free cash flows, risks in foreign exchange, growth, non-debt tax shields, political risks are potential determinants. The results showed that: for Japanese domestic firms, determinants of capital structure included profitability, size, and other factors such as firm age, agency costs, business risks, collateral value of assets, free cash flow; for multinational firms, the determinants of capital structure are similar to domestic firm (profitability, size, agency costs, business risks) and some more factors also have positive effect on firm leverage of multinational firms are: collateral, growth, non-debt tax shields and bankruptcy risk.

Sheikh and Wang (2011) explored 160 manufacturing firms in Pakistan during the periods from 2003-2007. In this research, debts to assets ratio represents for capital structure. The results showed that: (i) non-debt tax shields and growth opportunities are not significant to the capital structure; (ii) profitability, liquidity, earnings volatility, and tangibility have negative effects on capital structure; (iii) firm size has positive effect to capital structure.

Fauzi et al. (2013), investigated 79 New Zealand-listed firms for the period of 2007-2011. In this study, capital structure is dependent variable whereas asset structure, non-debt tax shields, profitability, growth, signaling, managerial ownership and firm size serves as independent variables. Leverage is measured as ratio of total debt over total assets, ratio of long-term debt over total assets, ratio of short-term debt over total assets. The results revealed that determinants of capital structure are managerial ownership, asset structure, growth and firm size. Nevertheless, non-debt tax shield and profitability do not show significant impact on capital structure.

Handoo and Sharma (2014) investigated 870 companies including both public sector and government companies of the period from 2001 to 2010 in India. In this study, the authors chose 3 proxies of capital structure: long-term debts to total assets, short-term debts to total assets and total debts to total assets. Ten independent variables (Profitability, Growth, Assets tangibility, Size, Cost of debt, Liquidity, Financial distress, Tax rate, Debt serving capacity, firm age) and three dependent variables (long-term debts to total assets, short-term debts to total assets and total debts to total assets) have been tested. It has been concluded that factors have significant impact on the capital structure are profitability, growth, asset structure, size, cost of debt, tax rate, and debt serving capacity.

Guruswamy and Marew (2016) examined Ethiopia's firm. The study investigated only insurance companies during the period of 2005-2014. In the study, firm leverage was used as capital structure and it is dependent variable. There are nine independent variables, included: growth opportunities, business risk, size of the firm, tangibility, liquidity, age, management efficiency, inflation and Gross Domestic Products. From the regression results, it is indicated that: economic growth rate, inflation rate, firm age, business risk, management efficiency identified as important determinants of capital structure. Nevertheless, firm growth has negative relation with capital structure. However, liquidity, size and tangibility of assets had insignificant impact on capital structure.

Al-Singlawi and Aladwan (2016) investigated impact of company's characteristics on capital structure of listed insurance companies in Jordan for the period 2010-2014. In this study, authors used the total debt to total assets ratio representing for capital structure. Variables considered as determinants of capital structure included profitability, size, structure of assets, growth in total assets and risk. Risk is measured by the difference in profitability and mean of profitability. The results showed a significantly negative effect between capital structure and the firm's growth, profitability, size, and risk. On the other hand, the capital structure has a positive relationship with asset structure. Moreover, the authors stated that profitable and large-size companies prefer internal financing rather than external debt. The companies in favor for debt when the probability of risk is very low.

Trinh and Phuong (2016) examined effects of financial crisis on capital structure of listed firms in Vietnam. The study discovered the relationship between capital structure and firm size, growth, profitability, tangibility, crisis dummies. Data sample includes 265 listed firms on Vietnamese stock market for the period of 2006-2013. The empirical result indicated that: firm size, profitability and tangibility have impacts on capital structure. On the other hand, the growth does not significant affect capital structure. Return on assets and tangibility have negative effects on capital structure. Finally, the result indicated that capital structure of listed firms in Vietnam has not changed during the crisis.

Mota and Moreira (2017) investigated 26 Portuguese companies for the period from 2006 to 2010. The results of the model after using FEM and REM and PCSE estimators showed that: tangibility, firm age have positive effects on the 
capital structure, whereas liquidity and non-debt tax shields have negative effects on leverage. Moreover, the author drew the conclusion that capital structure determinants of large Portuguese firms with investments in Angola were similar with those listed Portuguese firms. Thus, financing policy during the process of internationalization has not changed with investing firms and domestic firms.

Ilyukhin (2017) studied Russian companies for the period 2009-2015. In this research, Ilyukhin (2017) used 4 proxies for capital structure: total debt to market value of capital, total debt to book value of capital, long-term debt to market value of capital, long-term debt to book value of capital. In terms of potential determinants, the author proposed 13 factors: business risk, profitability, firm size, growth opportunities, capital expenditure, uniqueness, tangibility, average tax rate, depreciation, Industry mean leverage, stock market return, average lending rate, inflation rate. Some remarkable were shown in this study like: business risk, firm size, and inflation rate had a positive relationship to capital structure; profitability, growth opportunities had a negative relationship with capital structure; the tangibility had a mixed relationship to capital structure; the average tax rate did not have a statistically significant relationship with capital structure.

Akgul and Sigali (2018) studied transportation firm for the period 2002-2013. Total leverage and long-term leverage of the firm presenting for capital structure. The research results show that firm size has a positive relationship with leverage, while tangible assets have insignificant positive relationship with leverage. However, liquidity and profitability have significant negative relationship with leverage. Finally, growth opportunity, non-debt tax shield, volatility (business risk) have not shown statistically significant effects on leverage, corporate governance (board size, institutional ownership) has positively affected on leverage.

Huong (2018) explores factors influenced on capital structure of listed corporations in Vietnam. 464 non-financial biggest companies on the Vietnamese stock exchanges was investigated. Huong (2018) proposed size, profitability growth opportunities, tangible assets, liquidity, risk of bankruptcy as potential determinants of capital structure. The author used GMM regression to analyze the model. The results showed that the capital structure of listed corporations in Vietnam has positively affected by size, profitability, liquidity.

Kiraci and Aydin (2018) examined the factors that define capital structure of low-cost airlines. Capital structure was described through long term debt to total assets ratio and total debt to total assets ratio. In the study, 15 airline companies having continuous financial data during the 2004-2015 period were examined. Firm size, profitability, profitability, non-debt tax shield, asset structure, firm risk, liquidity ratio were potential determinants of capital structure. Driscoll-Kraay robust estimator results showed that asset structure and firm size have a positive influence on long-term debt but a negative influence on short-term debt. Also, profitability and growth opportunities have negative effect on total debt ratio in low-cost airlines.

Mustilli et al. (2018) examined the determinants of capital structure on a sample of 12,974 Italian firms. The analysis was conducted by using the SPSS 17.0 software. Companies included in the sample are limited and unlisted companies still in operation in 2016 and all the data needed for the analysis were available. Dependent variable is the ratio of debts from bank over total asset. Independent variables in their research included: size, growth, tangibility, non-debt tax shield, profitability, volatility of operating income over 5 years from 2012 to 2016. Results show that growth, size, tangibility and profitability are associated with debts from bank to total assets. Furthermore, the authors found that the return on equity significantly decreased in the deleverage period.

Almanaseer (2019) aimed to explore the determinants of the capital structure of the 13 banks listed in the Amman Stock Exchange of Jordan for the period 2008-2017. The relationship between financial leverage and firm characteristics such as risk, firm size, profitability, growth, liquidity, tax, firm age, tangibility, and macroeconomic variables such as Gross Domestic Products and inflation were investigated. The results of the study showed a significant positive relationship between financial leverage, age, growth, risk, size, and tax. Moreover, the study finds significant negative relationship between financial leverage and Gross Domestic Product, inflation, liquidity, profitability and tangibility.

Yousef (2019) studied the factors that influence the capital structure of the real estate industry in both GCC countries and United Kingdoms (UK). The capital structure is expressed in the ratio of debt to total assets (both book value and market value and includes short-term debt, long-term debt and total debt). Research data was from 131 companies during 2000 - 2014 in both GCC countries and UK. Yousef (2019) has included 5 variables that are likely to be factors affecting capital structure in his research: firm size, profitability, life cycle, firm growth and tangibility. The main research results have shown that: (i) firm size has a positive effect on capital structure in both GCC countries and UK; (ii) growth, profitability, life cylce adversely affect capital structure in both GCC countries and UK; (iii) 
finally, the effect of tangibility on GCC countries' capital structure is in the same direction but in the UK in opposite direction and this is the only difference between the two research contexts.

In summary, empirical studies show that capital structure or financial leverage can be influenced by factors such as firm size, business lines, profits, growth opportunities, and income tax rates, tangible assets, .... The results of the previous study are the basis for this study.

\section{Hypotheses Development}

\section{Firstly, firm performance and capital structure}

The more income of companies earned, the lower the probability companies go bankruptcy. High profit may encourage company to borrow more and then increase financial leverage. According to Trade-off theory, the company will borrow more from taking advantages of the tax shield. In studies, firm performance is often described by Return on Assets (ROA) and Return on Equity (ROE). However, existing studies do not have a consensus on the relationship between the profitability and the financial leverage. Some studies suggested that profitability has a positive effect on financial leverage or found no significant impact (Fauzi et al., 2013). Meanwhile, some studies have suggested that profitability has a negative effect on the financial leverage (Huang and Song, 2002; Chen, 2004; Sheikh and Wang, 2011; Al-Singlawi and Aladwan, 2016; Trinh and Phuong, 2016), Ilyukhin, 2017; Almanaseer, 2019). Therefore, this paper presents research hypotheses as follows:

Hla: Return on assets (ROA) has an opposite effect on the capital structure of listed companies on HOSE.

H1b: Return on equity (ROE) has opposite effect on the capital structure of listed companies on HOSE.

Secondly, firm size and capital structure

According to Titman and Welssels (1988), financial leverage and firm size are positively correlated because large -size companies and diversified operations will have a lower risk of bankruptcy compared to smaller- size companies. In other words, large companies will have the advantage of making borrowings compared to smaller companies. In addition, Ferri and Jones (1979) suggested that small companies are more likely to get interest rates higher compared to large company because from a bank's view, lending to small companies seem to be more risk. In addition, as pointed out in Diamond (1991), small companies often have limited access to loans. Therefore, financial leverage in large enterprises will be lower (Kester, 1986). Some studies also provide evidences to confirm that firm size is positively related to the capital structure of the company such as: Sheikh and Wang (2011), Trinh and Phuong (2016), Ilyukhin (2017), Akgul and Sigali (2018), Huong (2018), Kiraci and Aydin (2018). Otherwise, there are studies showing the negative relationship between firm size and capital structure such as: Al-Singlawi and Aladwan (2016) with research sample in Indonesia. Therefore, this paper suggests a research hypothesis as follows:

H2: Firm size has an opposite effect on the capital structure of listed companies on HOSE.

Thirdly, tangible fixed assets and capital structure

Tangible fixed assets show the ability of company to borrow money with collaterals for loan contracts. It is obvious that if the company has collaterals, the lender's risk will also be reduced so that many loans will be made. This argument is supported by many empirical studies such as Titman and Wessels (1988), Frank and Goyal (2009). Besides, according to the theory of intermediary cost, when collateral is used for borrowing, the intermediary cost associated with the debt will be lower, the business will borrow more and so on. The relationship between tangible fixed assets and debt will be positive. The positive relationship between tangibility and the capital structure of the company is also approved by many researchers: Chen (2004), Mota and Moreira (2017), Kiraci and Aydin (2018), Mustilli et al. (2018). On the other hand, some researchers disagree with the above statement: Sheikh and Wang (2011), Trinh and Phuong (2016), Akgul and Sigali (2018), Almanaseer (2019). Therefore, this paper proposes research hypothesis as follows:

H3: Tangibility has an opposite effect on the capital structure of listed companies on HOSE.

Fourth, risk and capital structure

Business risk is usually measured through volatility in earnings, in ROA or shares price over the years. The relationship between risk and capital structure attracts many researchers all over the world. According to Myers (2001), firms with high volatility in earnings will reduce borrowings because they are at high risk of bankruptcy. Firms with high volatility of earnings will not take advantage of tax incentives because they are more likely to be exposed to agency and bankruptcy costs. According to Antoniou et al. (2008), high risk companies will be at high risk of failing to fulfill their debt repayment commitments. In addition, Al-Najjar and Hussainey (2011) confirmed 
the negative effect between business risk and firm leverage in UK firms. In contrast, some authors (Jordan et al., 1998; Michaelas et al., 1999) realized that business risk is positively related to firm leverage while some authors stated no statistical effect of business risk on capital structure. Therefore, this paper addresses research hypothesis as follows:

H4: Risk has an opposite effect on the capital structure of listed companies on HOSE.

Fifth, firm growth and capital structure

Companies with high growth rates often need more capital to develop. According to Michaelas et al., (1999), when the company needs capital to serve its growth goals, if internal capital is insufficient, it will borrow from outside. This implied a positive relationship between firm growth and financial leverage. On the other hand, there are some researches (Titman and Wessels, 1988; Myers, 2001; Chen, 2004, Almanaseer, 2019) stated that the more growth rate, the lower rate of leverage. Those researchers explained that: when company reach high growth rates, companies will issue more shares instead of bonds and borrowing in order to minimize the profit sharing between owners and creditors. According to Myers (2001), high growth rates mean higher probability of bankruptcy and bankruptcy costs. Consistent with Myers (2001), Titman and Wessels (1988) also affirmed that fast-growing enterprises inherit the abundance in type of investment project and so that those enterprises also have higher intermediate costs. Therefore, the debt ratio will be assumed to be going down. However, some researchers argued that firm with high growth rates will increase debt, therefore financial leverage and firm growth is on the same direction (Al-Singlawi and Aladwan, 2016; Illyukhin, 2017; Kiraci and Aydin, 2018). Therefore, this paper proposes research hypothesis as follows:

H5: Firm growth has an opposite effect on the capital structure of listed companies on HOSE.

\section{Research Methodology}

\subsection{Research Model}

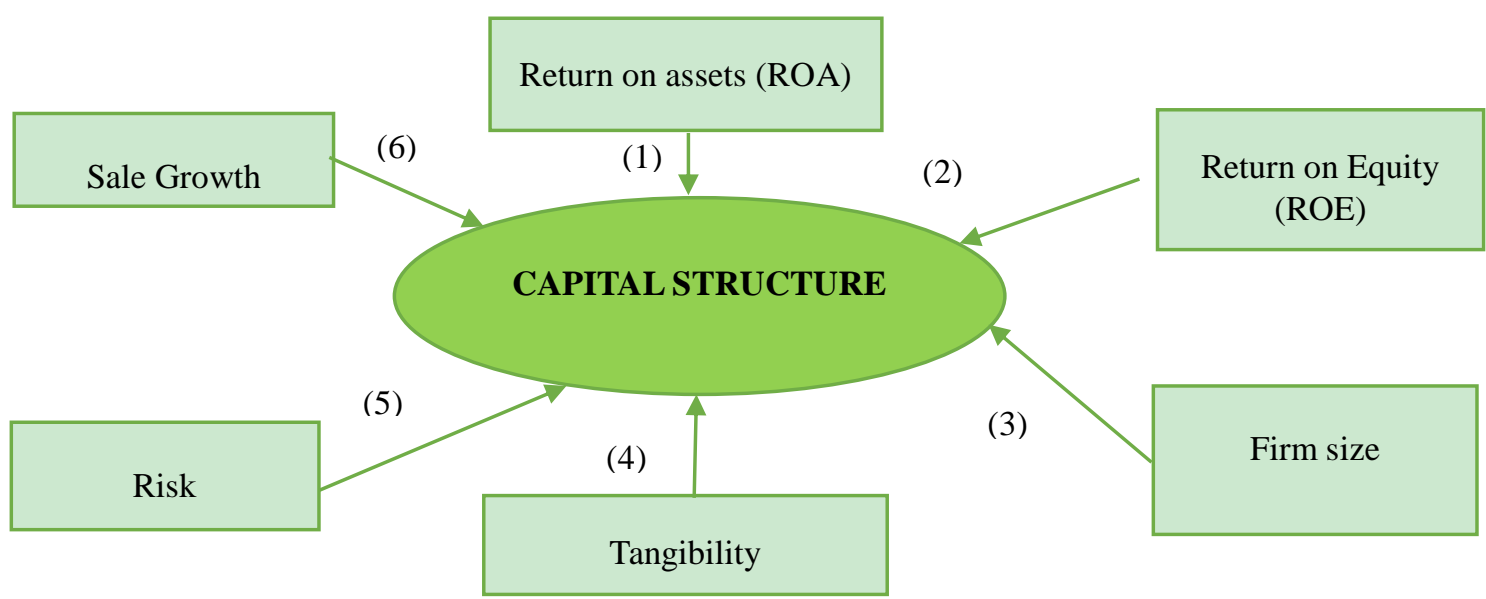

Figure 1. Research model

$$
\text { TDTA }_{\mathrm{i}}=\alpha_{0}+\alpha_{1} \text { ROA }_{\mathrm{i}}+\alpha_{2} \mathrm{ROE}_{\mathrm{i}}+\alpha_{2} \text { SIZE }_{\mathrm{i}}+\alpha_{3} \text { TANG }_{\mathrm{i}}+\alpha_{4} \mathrm{RISK}_{\mathrm{i}}+\alpha_{5} \mathrm{~S}_{-} \text {GROWTH }_{\mathrm{i}}+€
$$

Where:

TDTA: Capital structure

ROA: Return on assets

ROE: Return on equity

SIZE: Firm size

TANG: Tangibility

RISK: Business risk

S_GROWTH: Sale Growth 


\subsection{Data Sample}

This study uses data collected from the financial reports of 290 non-financial companies on HOSE during the period from 2010 to 2018 . Selected companies must have a fiscal year from $1^{\text {st }}$ January to $31^{\text {st }}$ December. Table 1 below describes the data used for this study.

Table 1. Variables measurement

\begin{tabular}{|c|c|c|c|}
\hline No & Variables & Measurement of variables & Previous studies \\
\hline 1 & TDTA & $\begin{array}{l}\text { TDTA }= \\
\text { Total Liability/Total assets }\end{array}$ & $\begin{array}{l}\text { Chen (2004), Huang and Song (2002), Sheikh } \\
\text { and Wang (2011), Al-Singlawi and Aladwan } \\
\text { (2016), Trinh \& Phuong (2016), Ilyukhin } \\
\text { (2017), Almanaseer (2019), Bevan and } \\
\text { Danbolt (2000) }\end{array}$ \\
\hline 2 & ROA & $\begin{array}{l}\text { ROA }= \\
\text { Earnings after tax / Average total } \\
\text { assets }\end{array}$ & $\begin{array}{l}\text { Titman and Wessels (1988), Trinh \& Phuong } \\
\text { (2016), Mustilli (2018) }\end{array}$ \\
\hline 3 & ROE & $\begin{array}{l}\mathrm{ROE}= \\
\text { Earnings after tax / Average total } \\
\text { equity }\end{array}$ & Dejan et al. (2013) \\
\hline 4 & SIZE & SIZE $=\ln$ (total assets) & $\begin{array}{l}\text { Sheikh and Wang (2011), Hadi (2014), } \\
\text { Al-Singlawi and Aladwan (2016), Trinh \& } \\
\text { Phuong (2016), Ilyukhin (2017), Akgul and } \\
\text { Sigali (2018), Kiraci and Aydin (2018), Huong } \\
\text { (2018), Mustilli (2018) }\end{array}$ \\
\hline 5 & TANG & $\begin{array}{l}\text { TANG }= \\
\text { Total tangible fixed assets/ Total } \\
\text { Assets }\end{array}$ & $\begin{array}{l}\text { Chen (2004), Sheikh and Wang (2011), Hadi } \\
\text { (2014), Trinh \& Phuong (2016), Mota and } \\
\text { Moreira (2017), Kiraci and Aydin (2018), } \\
\text { Akgul and Sigali (2018), Almanaseer (2019). }\end{array}$ \\
\hline 6 & RISK & $\begin{array}{l}\text { RISK is measured by volatility of } \\
\text { ROA. }\end{array}$ & Jordan et al. (1998); Michaelas et al. (1999) \\
\hline 7 & S_GROWTH & $\begin{array}{l}\text { Sale Growth }= \\
\left.\left(\text { Sale }_{t}-\text { Sale }_{t-1}\right) / \text { Sale }_{t-1}\right)\end{array}$ & Machek and Machek (2014) \\
\hline
\end{tabular}

\section{Empirical Results}

5.1 Descriptive Statistics Results

Table 2. Descriptive statistics results

\begin{tabular}{lllll}
\hline Variable Name & Mean & SD & Minimum & Maximum \\
\hline TDTA & 0.486 & 0.216 & 0.001 & 1.232 \\
\hline RISK & 0.045 & 0.034 & 0.002 & 0.256 \\
\hline TANG & 0.253 & 0.213 & 0.000 & 0.965 \\
\hline S_GROWTH & 0.272 & 2.085 & -1.000 & 74.602 \\
\hline ROE & 0.137 & 0.174 & -1.687 & 3.276 \\
\hline ROA & 0.072 & 0.087 & -0.625 & 0.743 \\
\hline SIZE & 27.842 & 1.325 & 20.720 & 32.254
\end{tabular}


Table 2 shows that the companies listed on HOSE have an average debt to total assets ratio of $48.6 \%$ (Mean $=0.486$ ). In addition, the value of fixed assets accounted for $25.3 \%$ of total assets (Mean $=0.253$ ). In terms of sale growth, companies have an average sale growth rate of $27.2 \%$ (Mean $=0.272$ ). In terms of profitability described by the value of ROA and ROE, listed companies have return on total assets $(\mathrm{ROA})$ of $7.2 \%$ (Mean $=0.072$ ) and return on equity $(\mathrm{ROE})$ is $13.7 \%$ (Mean $=0.137)$.

\subsection{Correlation Matrix}

Table 3. Correlation coefficient

\begin{tabular}{|c|c|c|c|c|c|c|c|}
\hline & TDTA & RISK & TANG & S_GROWTH & ROE & ROA & SIZE \\
\hline TDTA & 1 & & & & & & \\
\hline RISK & $-0.262 * * *$ & 1 & & & & & \\
\hline TANG & $-0.102 * * *$ & -0.006 & 1 & & & & \\
\hline S_GROWTH & -0.025 & 0.000 & $-0.049 * * *$ & 1 & & & \\
\hline $\mathrm{ROE}$ & $-0.108 * * *$ & $0.076 * * *$ & -0.019 & 0.012 & 1 & & \\
\hline $\mathrm{ROA}$ & $-0.473 * * *$ & $0.204 * * *$ & 0.025 & 0.005 & $0.702 * * *$ & 1 & \\
\hline SIZE & $0.325^{* * *}$ & $-0.074 * * *$ & $0.082 * * *$ & -0.017 & 0.021 & $-0.097 * * *$ & 1 \\
\hline
\end{tabular}

Note: $* * * \mathrm{p}<0.01, * * \mathrm{p}<0.05, * \mathrm{p}<0.1$

The correlation table shows that RISK, TANG, S_GROWTH, ROE and ROA are negatively correlated with TDTA. Regression coefficients received value of $-0.262,-0.102,-0.108,-0.473$ respectively. Inversely, firm size (SIZE) is positively correlated with TDTA (positive correlation coefficient $=0.325$ ). However, to assess the impact of independent variables on dependent variable, a regression analysis needs to be taken.

\subsection{Regression Analysis}

\subsubsection{Pooled Sample Regression Analysis}

After conducting Random Effects Model (REM) and Fixed Effects Model (FEM) regression, the author conducted tests to verify the reliability of the model and finally the authors selected the Generalized Method of Moments $(\mathrm{GMM})$ as the appropriate model for analysis and discussion the research results.

The results of the GMM in Table 4 indicate that: the ratio of fixed assets to total assets (TANG) has the opposite effect on debt ratio (coefficient $=-0.296$, p-value $<0.01$ ); Sale growth $($ S_GROWTH) has a negative effect on debt ratio (coefficient $=-0.0118, \mathrm{p}$-value $<0.01$ ); $\mathrm{ROE}$ has the same effect on debt ratio (coefficient $=0.0418, \mathrm{p}$-value $<0.01$ ); ROA negatively affects financial leverage (coefficient $=-0.378$, p-value $<0.01$ ); RISK negatively affects debt ratio $($ coefficient $=-0.703, \mathrm{p}$-value $<0.01$ ). Finally, firm size does not affect the debt ratio at significance level $10 \%$.

Table 4. Regression results for total group of companies

\begin{tabular}{llll}
\hline Variables & FEM & REM & GMM \\
\hline TANG & $-0.0340 *$ & $-0.0598 * * *$ & $-0.296 * *$ \\
\hline S_GROWTH & $0.00204 * *$ & 0.00161 & $-0.0118 * * *$ \\
\hline ROE & $0.147 * * *$ & $0.182 * * *$ & $0.0418 * * *$ \\
\hline ROA & $-0.799 * * *$ & $-0.935 * * *$ & $-0.378 * * *$ \\
\hline SIZE & $0.0279 * * *$ & $0.0352 * * *$ & -0.000392 \\
\hline RISK & & $-1.032 * * *$ & $-0.703 * * *$ \\
\hline Constant & $-0.244 * *$ & $-0.359 * * *$ & $0.249 * * *$
\end{tabular}

Note: $* * * \mathrm{p}<0.01, * * \mathrm{p}<0.05,{ }^{*} \mathrm{p}<0.1$ 


\subsubsection{Cross-Sector Regression Analysis}

In terms of comparison among sectors, Table 5a (see GMM column) has shown the results. Taking Industry companies (L1) for reference, it means that this paper conducts comparison debt ratio between Industry sector and other 7 sectors (Infor and Telecom (L2), Pharmacy (L3), Oil \& Gas (L4), Service for Consumer (L5), Goods for consumer (L6), Materials (L7) and Utilities (L8)). The results indicated that the Pharmacy has a higher debt than the Industry (reference coefficient $=0.272>0$ ); Goods for Consumer tends to use lower debt ratio than Industry (regression coefficient $=-0.045$ ); and the Materials also use a lower debt ratio than Industry (regression coefficient $=$ $-0.046<-0.045)$. Therefore, the Materials (L7) have a lower debt ratio than the Goods for Consumers (L6). Other sectors did not show any differences on the use of debt. The ranking order of debt ratio level is shown in Table $5 \mathrm{~b}$ below.

Table 5a. Cross-sectors regression results

\begin{tabular}{llll}
\hline Variables & FEM & REM & GMM \\
\hline TANG & $-0.0340^{*}$ & $-0.0598^{* * *}$ & $-0.296^{* * *}$ \\
\hline S_GROWTH & $0.00204^{* *}$ & 0.00161 & $-0.0118^{* * *}$ \\
\hline ROE & $0.147^{* * *}$ & $0.182^{* * *}$ & $0.0418^{* * *}$ \\
\hline ROA & $-0.799^{* * *}$ & $-0.935^{* * *}$ & $-0.378^{* * *}$ \\
\hline SIZE & $0.0279^{* * *}$ & $0.0352^{* * *}$ & -0.000392 \\
\hline RISK & & $-1.032^{* * *}$ & $-0.703^{* * *}$ \\
\hline Infor \& Telecom (L2) & $-0.0824^{*}$ & 0.0262 \\
\hline Pharmacy (L3) & $-0.128^{* * *}$ & $0.272^{* * *}$ \\
\hline Oil \& Gas (L4) & -0.0674 & 0.152 \\
\hline Service for consumer (L5) & -0.00126 & 0.0183 \\
\hline Goods for consumer (L6) & & -0.0302 & $-0.0455^{* *}$ \\
\hline Materials (L7) & & $-0.0532^{* *}$ & $-0.0468^{* *}$ \\
\hline Utilities (L8) & -0.0363 & $-0.110^{*}$ \\
\hline Constant & $-0.244^{* *}$ & $-0.359^{* * *}$ & $0.249^{* * *}$ \\
\hline
\end{tabular}

Note: $* * * \mathrm{p}<0.01, * * \mathrm{p}<0.05, * \mathrm{p}<0.1$

Table 5b. Ranking of debt ratio among sectors

\begin{tabular}{ll}
\hline No. & Name of sector \\
\hline 1 & Pharmacy (L3) \\
\hline 2 & Industry (L1) \\
\hline 3 & Goods for Consumer (L6) \\
\hline 4 & Materials (L7) \\
\hline 5 & Utilities (L8) \\
\hline
\end{tabular}

\subsubsection{Results of Determinants Among Sectors}

The results of the impact factors on capital structure have been shown in Table 6 below.

Table 6. Result of the impact factors on capital structure among sectors

\begin{tabular}{lllllllll}
\hline Variables & L1 & L2 & L3 & L4 & L5 & L6 & L7 & L8 \\
\hline RISK & -0.258 & 0 & -0.345 & -247.7 & $-1.043^{* *}$ & $-0.814^{* * *}$ & $-3.237^{* * *}$ & -0.998 \\
\hline TANG & $-0.192^{* * *}$ & -0.154 & -0.200 & 0.500 & $-0.216^{* * *}$ & 0.0692 & $-0.425^{* * *}$ & -0.0119 \\
\hline S_GROWTH & $-0.00675^{*}$ & -0.0170 & $-0.00736^{*}$ & $-0.083^{* *}$ & 0.00754 & $-0.00280^{* * *}$ & $-0.0239^{* * * *}$ & 0.0178 \\
\hline
\end{tabular}




\begin{tabular}{lllllllll}
\hline ROE & $0.968 * * *$ & 0.150 & $0.977 * *$ & -0.0919 & 0.0676 & $0.315 * * *$ & $0.0266 * * *$ & $0.858 * * *$ \\
\hline ROA & $-3.144 * * *$ & -0.489 & $-1.611 * *$ & -0.114 & $-0.454 * *$ & $-1.131 * * *$ & $-0.112 *$ & $-1.618 * * *$ \\
\hline SIZE & -0.00213 & 0.193 & -0.0164 & $0.345 *$ & -0.0103 & 0.00444 & $0.0228 * * *$ & -0.00702 \\
\hline Constant & $0.535 * *$ & -5.115 & 0.684 & -1.188 & $0.584 *$ & 0.132 & $-0.701 * * *$ & $0.523 * *$ \\
\hline Observations & 862 & 72 & 121 & 17 & 191 & 535 & 428 & 224 \\
\hline AR (2) & 0.635 & 0.434 & 0.409 & 0.755 & 0.579 & 0.397 & 0.644 & 0.975 \\
\hline Hansen test & 0.873 & 0.887 & 0.287 & 0.247 & 0.566 & 0.295 & 0.343 & 0.995
\end{tabular}

Note: $* * * \mathrm{p}<0.01, * * \mathrm{p}<0.05, * \mathrm{p}<0.1$

L1: Industry, L2: Infor \& Telecom, L3: Pharmacy, L4: Oil \& Gas; L5: Service for consumer; L6: Goods for consumer; L7: Materials; L8: Utilities.

Table 6 shows that: RISK has the opposite effect on TDTA in consumer services companies, consumer goods companies and materials companies (coefficients $=-1.043 ;-0.814 ;-3.237$, respectively). RISK does not affect TDTA in other sectors. Moreover, TANG has the opposite impact on TDTA in Industry companies, Consumer services companies, Raw materials companies (coefficients $=-0.192 ;-0.216$; -0.425 , respectively) while S_GROWTH has negatively affected TDTA in Industry companies, Pharmacy companies, Oil \& Gas companies, Goods for consumer companies and Materials companies (coefficient $=-0.00675 ;-0.00736 ;-0.083 ;-0.00280 ;-0.0239$, respectively). In addition, ROE has the same impact on TDTA of Industry companies, Pharmacy companies, Goods for consumer companies, Materials companies and Utilities companies (coefficients $=0.968 ; 0.977 ; 0.315 ; 0.0266 ; 0.858$, respectively). ROA negatively affects TDTA in Industry companies, Pharmacy companies, Service for consumer companies, Goods for consumer companies and Utilities companies (coefficient = -3.144; $-1.611 ;-0.454 ;-1.131$; -1.618 , respectively).

Finally, Firm size (SIZE) only has a positive impact on TDTA in the Oil and gas companies and Materials companies (coefficients $=0.345 ; 0.0228$, respectively). Table 7 below summarizes the impact of factors across industries.

Table 7. Summary of results on determinants of capital structure among companies listed on HOSE

\begin{tabular}{lllllllll}
\hline Variables & L1 & L2 & L3 & L4 & L5 & L6 & L7 & L8 \\
\hline RISK & No & No & No & No & - & - & - & No \\
\hline TANG & - & No & No & No & - & No & - & No \\
\hline S_GROWTH & - & No & - & - & No & - & - & No \\
\hline ROE & + & No & + & No & - & + & + & + \\
\hline ROA & - & No & - & No & No & - & - & - \\
\hline SIZE & No & No & No & + & No & No & + & No \\
\hline
\end{tabular}

Note: (+) Positive effect, (-): negative effect, No: No statistically significant effect.

L1: Industry, L2: Infor \& Telecom, L3: Pharmacy, L4: Oil \& Gas; L5: Service for consumer; L6: Goods for consumer;

L7: Materials; L8: Utilities.

\section{Discussion and Recommendations}

\subsection{Discussion}

Firstly, the results obtained from GMM regression in Table 4 have shown that ROA has a negative effect on financial leverage. Therefore, the hypothesis H1a is accepted. This research is consistent with the results of Huang and Song (2002), Chen (2004), Sheikh and Wang (2011), Al-Singlawi and Aladwan (2016), Trinh and Phuong (2016), Ilyukhin (2017), Almanaseer (2019). 
Secondly, the results obtained from GMM regression in Table 4 have shown that ROE has a positive effect on financial leverage. This is quite reasonable because when the company needs to raise capital, the company will increase its debt rather than equity so the amount of equity will remain. Therefore, with a constant level of profit, the rate of return on equity will increase if the company increases its liabilities. Thus, hypothesis $\mathrm{H} 1 \mathrm{~b}$ is not accepted.

Thirdly, the results obtained from GMM regression in Table 4 have shown that SIZE has no effect on financial leverage of the overall listed companies on HOSE. When studying the sample of oil \& gas companies and materials companies, the author realized that there is a positive effect between company size and financial leverage. This research is consistent with the results of Chen (2004), Mota and Moreira (2017), Kiraci and Aydin (2018). However, the hypothesis $\mathrm{H} 2$ is not accepted because the hypothesis mentioned on the sample of all listed companies on HOSE.

Fourth, the results obtained from GMM regression in Table 4 have shown that the proportion of fixed assets in total assets (TANG) has the opposite effect on financial leverage. Therefore, the hypothesis H3 is accepted. The results of this study are consistent with the results of Sheikh and Wang (2011), Trinh \& Phuong (2016), Akgul and Sigali (2018), Almanaseer (2019).

Fifth, the results obtained from GMM regression in Table 4 have shown that business risk has a negative effect on financial leverage. In this paper, business risk is expressed through the volatility of ROA. Research results have shown that the more ROA volatile a company is, the harder to make loans and thus the financial leverage will decrease. Many studies have also drawn this conclusion: Myers (2001); Antoniou et al. (2008); Al-Najjar and Hussainey (2011). Therefore, the hypothesis $\mathrm{H} 4$ is accepted.

Sixth, the results obtained from GMM regression in Table 4 have shown that sale growth has a negative effect on financial leverage. That means when the company achieves a high level of growth, it can be able to use equity for its operating activities and reduce its dependence on creditors. This is consistent with pecking order theory. Thus, the hypothesis H5 is accepted. This result is consistent with the results of Titman and Wessels (1988); Chen (2004); Almanaseer (2019).

\subsection{Recommendations}

To business managers: The research results have shown that when the risk (RISK) is high, the financial leverage in all listed companies decreases. This information is very important for managers in making borrowing decisions because it is not always possible for the business to benefit from the loan due to the deduction in income tax. When risks are high, businesses face a high risk of bankruptcy. Therefore, managers need to be cautious. They should reduce debt and use equity properly. In addition to that, they should evaluate the effectiveness of using loans, eliminating loans inefficient.

To investors: The research results draw the conclusion that the growth rate (S_GROWTH) has a negative impact on the company's debt ratio. It means that: as the company grows, the companies will reduce the debt and thus net income will be distributed to the owners. This study has provided useful information to help investors make good decisions to contribute capital for dividend or to lend it for interest income.

To banks and credit institutions: Research results on a sample of 290 non-financial companies listed on HOSE in this article have shown that the return on asset (ROA) has a negative impact on the debt ratio. Thus, the companies with low business results, the debt ratio increases. Therefore, when appraising loan documents of businesses, credit officers need to carefully assess the financial situation and business results to ensure loan repayment. At the same time, banks and credit officers must regularly monitor the business situation during the borrowing period.

\section{Conclusion}

This paper has studied the impact of ROA, ROE, size, tangibility, risk and growth on capital structure of companies listed on HOSE, Vietnam. This study provided empirical evidences that all these factors affect capital structure except firm size. Besides, when analyzing across sectors, the research results showed different level of influence of factors on capital structure. Moreover, the results showed that Pharmacy sector is the leading sector in term of the debt to the total assets ratio, followed by Industry, Goods for consumer, Material, Utilities. The research results of the study enrich the previous studies worldwide on the factors on corporate leverage. Based on the results of this research, the authors have made some proposals for business managers, investors, banks and credit institutions in Vietnam in making decisions. This study also has some limitations, which are just studying the company's characteristics affecting the capital structure. Future studies may add macro-environmental factors such as economic growth (Gross domestic products, Gross National Products, ...) and the technology development of country to consider the influence of these factors on the capital structure of enterprises, thereby helping enterprise's managers and state management agencies to make decisions effectively. 


\section{References}

Akgul, E., \& Sigali, S. (2018). Determinants of capital structure: An Application on BIST transportation index. Journal of Accounting \& Finance, 1(2), 193-215. https://doi.org/10.25095/mufad.401506

Akhtar, S., \& Oliver, B. (2009). Determinants of capital structure for Japanese multinational and domestic corporations. International Review of Finance, 9(1-2), 1-26. https://doi.org/10.1111/j.1468-2443.2009.01083.x

Almanaseer, S. R. (2019). Determinants of capital structure: evidence from Jordan. Accounting and Finance Research, 8(4), 186-198. https://doi.org/10.5430/afr.v8n4p186

Al-Najjar, B., \& Hussainey, K. (2011). Revisiting the capital structure puzzle: UK evidence. The Journal of Risk Finance, 12(4), 329-338. https://doi.org/10.1108/15265941111158505

Al-Singlawi, O., \& Aladwan, M. (2016). Company's characteristics \& capital structure: an empirical study on listed insurance companies in Jordan. Journal of Management Research, 8(2), 103-118. https://doi.org/10.5296/jmr.v8i2.9141

Antoniou, A., Guney, Y., \& Paudyal, K. (2008). The determinants of capital structure: capital market oriented versus bank-oriented institutions. Journal of Financial and Quantitative Analysis, 43(1), 59-92. https://doi.org/10.1017/S0022109000002751

Arellano, M., \& Bond, S. (1991). Some tests of specification for panel data: Monte Carlo evidence and an application to employment equations. The Review of Economic Studies, 58(2), 277-297. https://doi.org/10.2307/2297968

Booth, L., Aivazian, V., Kunt, A. D., \& Maksimovic, V. (2001). Capital structures in developing countries. The Journal of finance, LVI (1), 87-130. https://doi.org/10.1111/0022-1082.00320

Burgman, T. A. (1996). An empirical examination of multinational corporate capital structure. Journal of International Business Studies, 27(3), 553-570. https://doi.org/10.1057/palgrave.jibs.8490143

Chen. J. J. (2004). Determinants of capital structure of Chinese-listed companies. Journal of Business Research, 57(12), 1341-1351. https://doi.org/10.1016/S0148-2963(03)00070-5

Dejan, M., Ksenija, D. M., \& Ema, L. (2013). The determinants of capital structure in emerging capital markets: evidence from Serbia. European Research Studies, XVI (2), 98-119. https://doi.org/10.35808/ersj/391

Fauzi, F., Basyith, A., \& Idris, M. (2013). The Determinants of capital structure: an empirical study of New Zealand-listed firms. Asian Journal of Finance \& Accounting, 5(2), 1-21. https://doi.org/10.5296/ajfa.v5i2.3740

Ferri, M. G., \& Jones, W. H. (1979). Determinants of financial structure: a new methodological approach. The Journal of Finance, 34(3), 631-644. https://doi.org/10.1111/j.1540-6261.1979.tb02130.x

Frank, M. Z., \& Goyal, V. K. (2009). Capital structure decisions: which factors are reliably important?. Financial Management, 38(1), 1-37. https://doi.org/10.1111/j.1755-053X.2009.01026.x

Fraser, R. D., Zhang, H., \& Derashid, C. (2006). Capital Structure and political patronage: the case of Malaysia. Journal of Banking and Finance, 30(1), 1291-1308. https://doi.org/10.1016/j.jbankfin.2005.05.008

Guruswamy, D., \& Marew, A. (2016). Determinants of capital structure of selected insurance companies in Ethiopia. Developing Countries Studies, 6(10), 6-20.

Handoo, A., \& Sharma, K. (2014). A study of determinants of capital structure in India. IIMB Management Review, 26(2), 170-182. https://doi.org/10.1016/j.iimb.2014.07.009

Huang, G. H. S., \& Song, F. M. (2002). The Determinants of the capital structure: evidence from China. China Economic Review, 1(2), 14-36. https://doi.org/10.1016/j.chieco.2005.02.007

Huong, P. T. Q. (2018). Macroeconomic factors and corporate capital structure: evidence from listed joint stock companies in Vietnam. International Journal of Financial Research, 9(1), 31-40. https://doi.org/10.5430/ijfr.v9n1p31

Ilyukhin, E. V. (2017). The determinants of capital structure: evidence from Russia. Journal of Corporate Finance Research, 14(4), 54-69. https://doi.org/10.17323/j.jcfr.2073-0438.11.4.2017.54-69

Jensen, M. (1986). Agency costs of free cash flow, corporate finance, and takeovers. American Economic Review, $76(2), 323-29$. 
Jensen, M. C., \& Meckling, W. H. (1976). Theory of the firm: managerial behavior, agency costs and ownership structure. Journal of Financial Economics, 3(4), 305-360. https://doi.org/10.1016/0304-405X(76)90026-X

Jordan, J., Lowe, J., \& Taylor, P. (1998). Strategy and financial management in UK small firms. Journal of Business Finance and Accounting, 25(1), 1-27. https://doi.org/10.1111/1468-5957.00176

Kester, C. W. (1986). Capital and ownership structure: a comparison of United States and Japanese manufacturing corporations. Financial Management, 15(1), 5-16. https://doi.org/10.2307/3665273

Kiraci, K., \& Aydin, N. (2018). Determinants of capital structure: empirical evidence from traditional airlines. International Journal of Economic \& Administrative Studies, 21(2), 173-186.

Kraus, A., \& Litzenberger, R. H. (1973). A state-reference model of optimal financial leverage. The Journal of Finance, 28(2), 911-922. https://doi.org/10.1111/j.1540-6261.1973.tb01415.x

Machek, O., \& Machek, M. (2014). Factors of business growth: a decomposition of sales growth into multiple factors. WSEAS Transactions on Business and Economics, 11(35), 380-385.

Michaelas, N., Chittenden, F., \& Poutziouris, P. (1999). Financial policy and capital structure choice in U.K. SMEs: empirical evidence from company panel data. Small Business Economics, 12(2), 113-130. https://doi.org/10.1023/A:1008010724051

Modigliani, F., \& Miller, M. H. (1958). The cost of capital, corporation finance and the theory of investment. The American Economic Review, 48(3), 261-297.

Mustilli, M., Campanella, F., \& D’Angelo, E. (2018). Measuring determinants and effects of firms' financial structure in a deleverage setting: evidence from Italy. International Journal of Financial Research, 9(2), 23-30. https://doi.org/10.5430/ijfr.v9n2p23

Myers, S. C. (2001). Capital structure. The Journal of Economic Perspectives, 15(2), 81-102. https://doi.org/10.1257/jep.15.2.81

Rajan, R. G., \& Zingales, L. (1995). What do we know about capital structure? some evidence from international data. Journal of Finance, 50(1), 1421-1460. https://doi.org/10.1111/j.1540-6261.1995.tb05184.x

Sheikh, N. A., \& Wang, Z. J. (2011). Determinants of capital structure: an empirical study of firms in manufacturing industry of Pakistan. Managerial Finance, 37(2), 117-133. https://doi.org/10.1108/03074351111103668

Titman, S., \& Wessels, R. (1988). The determinants of capital structure choice. The Journal of Finance, 43(1), 1-19. https://doi.org/10.1111/j.1540-6261.1988.tb02585.x

Trinh, T. H., \& Phuong, N. T. (2016). Effects of financial crisis on capital structure of listed Firms in Vietnam. International Journal of Financial Research, 7(1), 66-74. https://doi.org/10.5430/ijfr.v7n1p66

Yousef, I. (2019). The Determinants of Capital Structure: Evidence from GCC and UK real estate sectors. Real Estate Management and Valuation, 27(2), 108-125. https://doi.org/10.2478/remav-2019-0019 